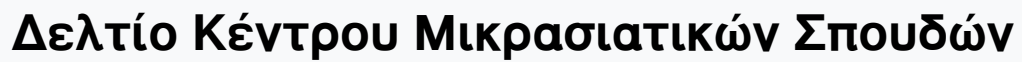

Tóp. 3 (1982)

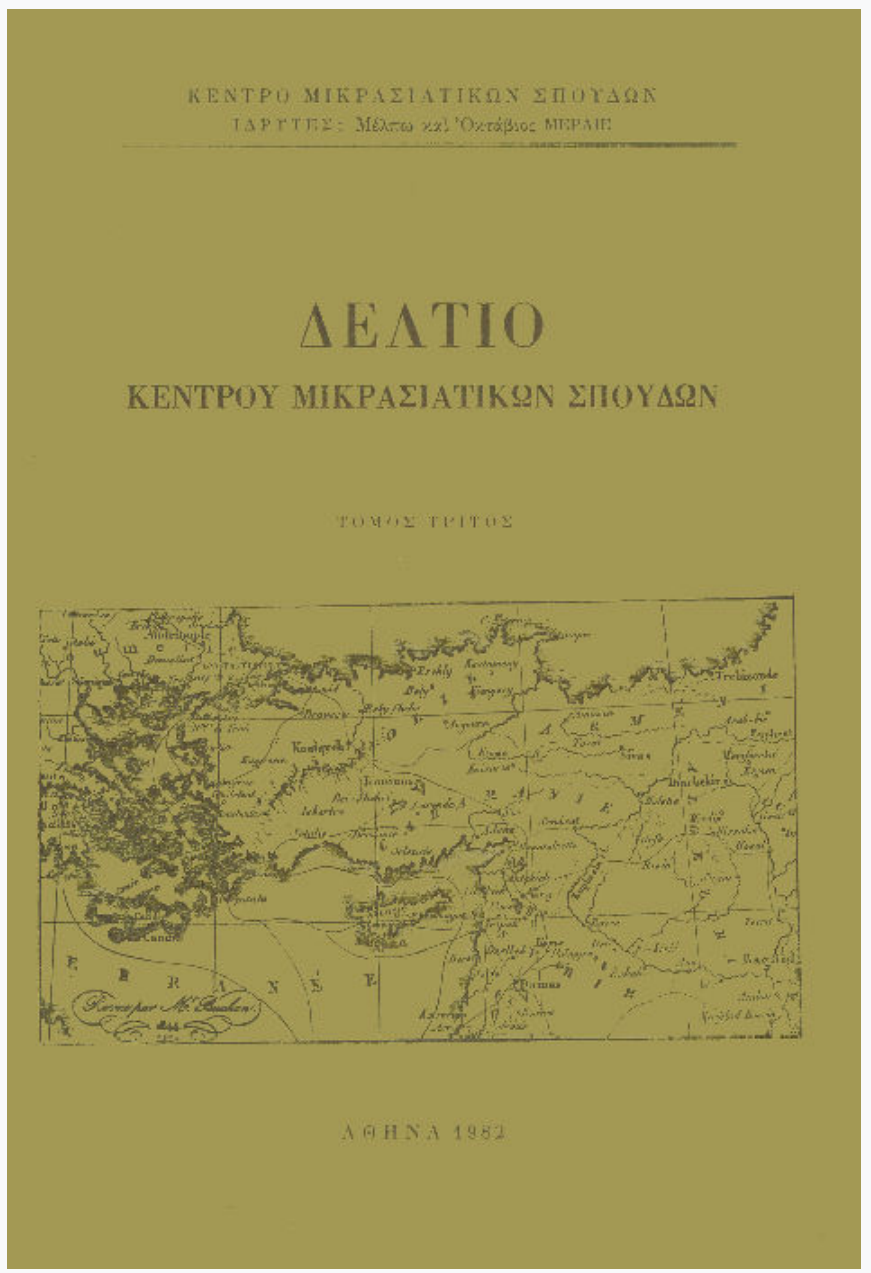

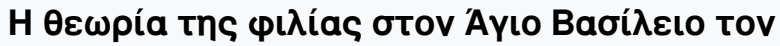

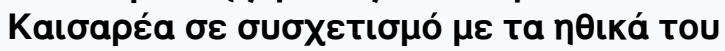

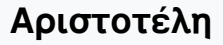

Carla Spadavecchia

doi: $\underline{10.12681 / \text { deltiokms.278 }}$

Copyright @ 2015, Carla Spadavecchia

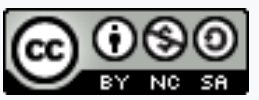

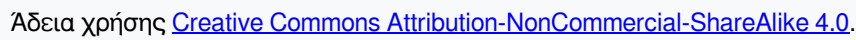

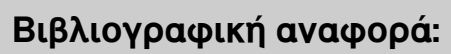

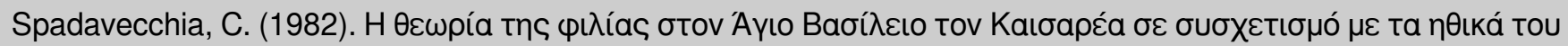

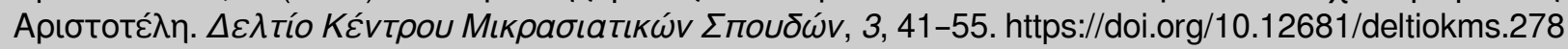




\section{A THEORY OF FRIENDSHIP IN ST. BASIL OF CAESAREA, IN RELATION TO ARISTOTLE'S ETHICS}

This study intends to outline some similarities between the notion of friendship, as evinced by St. Basil of Caesarea in his Letters ${ }^{1}$, and Aristotle's theory of friendship, as is expressed in both the Nicomachean and the Eudemian Ethics ${ }^{2}$.

I shall underline some views and opinions on this topic, common both to the Greek philosopher and to the Cappadocian Father, which appear to point to a conscious derivation from Aristotle on Basil's part. On the other hand, if it is difficult to trace a logical development in the history of theories of friendship in Greek classical philosophy ${ }^{3}$, it is even more difficult to state with certainty whether or not any such theories have directly influenced St. Basil's views on the subject. Basil received a thorough classical education in Athens ${ }^{4}$, but soon the way of life he chose carried him far away from philosophical studies, and plunged him into theological controversies and ecclesiastical concerns. It is true that he never rejected, nor seemed to have forgotten, his classical learning $^{5}$, but he did not adhere to it with the same confident enthusiasm which Gregory of Nazianzus always showed ${ }^{6}$; nor are his references to and

1. The Letters will be quoted in the translation by R. Deferrari (Loeb, four vols.), with occasional minor changes. As for the numbering of lines, reference will be made to the ed. by Y. Courtonne (Budé, three vols.), as there is no such notation in the Loeb ed.

2. See $N E$ VIII and IX; $E E$ VII (tr. R. Rackham, Loeb). For a discussion of the relationship between the $E E$ and the $N E$, see A. Kenny, The Aristotelian Ethics (Oxford 1978). On the basis of philological, historical and philosophical arguments, Kenny proves the inadequacy of the widely accepted idea of the comparative earliness of the $E E$ and the comparative lateness of the $N E$.

3. See L. Dugas, L'amitié antique (Diss. Paris 1894) 247.

4. He followed the usual curriculum, and apparently excelled in rhetoric, grammar and philosophy: see Gr. Naz., or. 43, ch. 23.

5. Cf. Ep. 340 in the Deferrari ed., written by Libanius to Basil (especially lines 23 to the end).

6. In her work Gregory of Nazianzus. Rhetor and Philosopher (Oxford 1969) 16, R. Radford Ruether regards Gregory as the writer who «stands for that fourth-century 
echoes of the classics so conspicuous as in Gregory. When one considers Basil's specific ideas about friendship, therefore, it is not easy to distinguish what Basil may have borrowed from the classics and what he may have felt as normal human experience - enhanced by Christianity, - without any need for dependence on Greek theorists.

On the other hand, he may have experienced in a deeper way such feelings as the need of friends, or the pleasure which comes from a friendly relationship, not only through his natural sensitivity, but also because the classical theories about friendship, still alive in his mind, whether more or less at a conscious level, helped him to give a more accurate expression to his personal feelings and to his attitude towards friends. Of all the classical writers whose influence can be detected in Basil on the topic of friendship, Aristotle seems to have had the strongest effect. One reason for this predilection is certainly the fact that he views friendship in a more personal way than Plato and the Stoics do ?. After equating goodness with friendliness, and after defining friendship as "a state of the moral character" ${ }^{8}$, the writer of the $E E$ adds: «We consider a friend to be one of the greatest goods, and friendlessness and solitude a very terrible thing, because the whole of life and voluntary association is with friends» ${ }^{9}$. Such a positive statement on the value of friendship, and on the unhappiness which arises from lack of it, is in total agreement with the attitude displayed by Basil throughout his Letters. Aristotle realized that friendship is addressed to the person; that is, to the virtuous person, and not to the virtue abstractly considered. In the same way, Basil's letters to friends are deeply rooted in his life, while, at the same time, he considers virtue as the bond - as well as the common aim that he has with friends ${ }^{10}$. There can be found, in the Aristotelian Ethics,

phenomenon, the Christian rhetor, the creator of a renaissance of letters within the Church", but she also points out the "striking conflict between his actual indebtedness to classical sources and his conscious attitudes towards Greek rhetoric and philosophy".

7. "The suprapersonal ground of the value of the human relationship no longer diverts attention from the personality of the friend; on the contrary, it is concentrated and incarnated within" (W. Jaeger, Aristotle-Fundamentals of the History of his Development, tr. R. Robinson (Oxford 1960) 244).

8. $E E 1234$ b $27-28$.

9. EE 1234 b $32-34,1235$ a 1.

10. Basil mentions $\varphi \imath \lambda i \alpha$ as an instance of virtue (or goodness) in Ep. 83, addressed

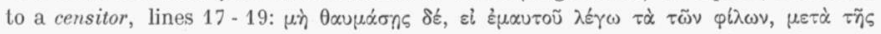

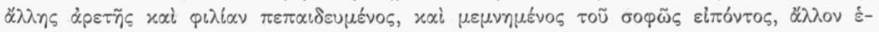

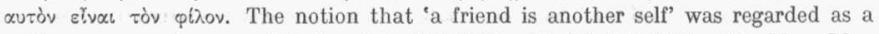
pythagorean sentence, and is found in NE 1166 a 31 (cf. EE 1245 a 30; Mag. Mor. 


\section{A THEORY OF FRIENDSHIP IN ST. BASIL OF CAESAREA}

seven themes at least which are reflected in Basil's Letters, though not always explicitly expressed.

a) Friendship is useful: Aristotle ${ }^{11}$ quotes Homer (Il. 10.224) and adds: «for two are better able both to plan and to execute». Basil too resorts to his friends for spiritual purposes - and not seldom for wordly purposes as well, when he asks for favours from local authorities, such as reduction of taxes ${ }^{12}$ and exemptions from offices or burdens of many kinds ${ }^{13}$. Conversely, he gives advice in order to help friends who need to be guided, or heartened, or admonished ${ }^{14}$. For Basil, therefore, mutual help is one of the characteristics of friendship. He writes to Eusebius of Samosata ${ }^{15}$ : "Before our departure from this life may God deem us worthy

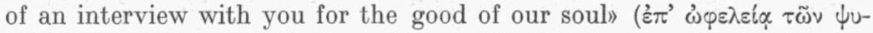
$\chi \tilde{\omega} \nu \dot{\eta} \mu \tilde{\omega} \nu)$. And to the Senate of Tyana ${ }^{16}$ : «We know very clearly that we need the help of each and every brother more than one hand needs

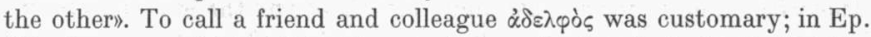
172, for example, Basil rejoices at bishop Sophronius' charity ${ }^{17}$ : "For nothing is so rare now as a meeting with a spiritual brother" (oủ $\delta \dot{\varepsilon} v \gamma \alpha \dot{\rho}$

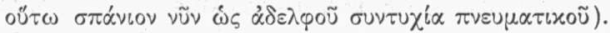

b) Resemblance in virtue and identity of spiritual aims are the foundations required for a sincere friendship: we read in the $N E^{18}$ that "the perfect form of friendship is that between the good, and those who resemble each other in virtue». The same can be detected in the relationships between Basil and such men as, for example, Eusebius of Samosata and

1213 a 23 - 24). But it had become too much of a commonplace (cf. Cic. Amic. 21.80) to be proved as a specific reference to Aristotle - although the mention of friendship as a virtue points in his direction.

11. NE 1155 a 15.

12. See, e.g., Epp. 35, 36, 37, 83, 88 (where he pleads for an extension of time for the payment of taxes), 284.

13. See, e.g., Ep. 84 (on behalf of an old man, who was obliged to serve again, in spite of his age, because his four-year-old grandson had been placed on the senatorial roll). See also Epp. 142 (to the prefects' accountant), 143, 144.

14. Cf. letters of spiritual direction, letters of consolation, and letters to friends in general. That friendship helps recovery from spiritual illnesses, in a topos : see G.

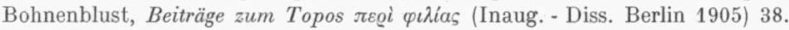

15. Ep. 136, end.

16. Ep. $97,10-12$.

17. lines $7-8$,

18. $1156 \mathrm{~b} 6-7$. Cf. $E E 1236 \mathrm{~b} 1-3$ : «(But) the friendship in conformity with goodness is the friendship of the best men. It is clear from this that the primary friendship, that of the good, is mutual reciprocity of affection and purpose». 


\section{CARLA SPADAVECCHIA}

other fellow-bishops, or also laymen who were moved, like Basil, by the same «love towards both God and neighbour» ${ }^{19}$. Basil kept in touch only with those people with whose ideals he was able to agree. One cannot expect from him any statements about his own virtues, but it is certain that he could establish relationships of friendship only with those who were of: "one body and one mind» ${ }^{\mathbf{2 0}}$ with him. Evidence of this can be found in Epp. 63 and 64. The former, addressed to the governor of Neocaesarea in about 371, deserves extensive quotation: "The wise man, even though he dwell in a distant land, though I may never behold him with my eyes, I account my friend', is a saying of the tragic poet Euripides ${ }^{21}$. If, therefore, in spite of the fact that no face-to-face meeting has as yet given us the pleasure of acquaintance with your Magnanimity, we say that we are your friend and associate, do not consider this assertion to be flattery. For, as the promoter of our friendship, we have Fame, who with mighty voice proclaims your deeds to all mankind... We have come to know you as well, and have been as utterly captivated by you, as if we had been associated with you for a long time, and had knowledge of your noble qualities through long experience... your magnanimity, the loftiness of your spirit, the gentleness of your manners, experience in affairs, sagacity of judgement, dignity of life mingled with affability, ability as an orator, and many other qualities... which we cannot mention to you now without earrying the letter beyond its proper limits. How, then, could I help loving such a man? How, at any rate, could I so far control myself as not with loud voice to make known my soul's emotion? Accept, therefore, admirable sir, the appellation ${ }^{22}$, which is applied to you of a friendship that is true and genuine; for our character is far removed from servile adulation ${ }^{23}$; may you keep us numbered in the roll of your friends, by frequent letters, both showing

19. Ep. 9, to Maximus the philosopher, lines $4-5$.

20. This expression, ascribed to Diogenes and Pythagoras, is very frequently resorted to throughout antiquity (cf. $E E 1240$ b 3). See Bohnenblust (op.cit., note 14 supra) 40 , who rightly states that, on the other hand, the Christian writers are likely

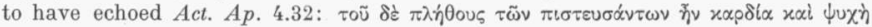

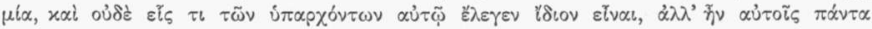
xotvá.

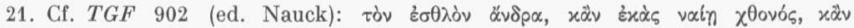

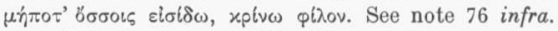

22. i.e., the name of 'friend'.

23. "Das Zerrbild der Freundschaft ist die Schmeichelei», states Bohnenblust (op. cit., note 14 supra) 31, offering evidence from Aristotle as well as from Cicero. 
yourself to us and consoling us for your absence». The language and style which Basil uses here could as well fit a letter of recommendation: but, in fact, Basil is not asking for any material help or support for his clientes. In a similar way, a passage from the $E E^{24}$ stresses the gratuitousness of a sincere friendship: "Therefore since the primary sort of friendship is in accordance with goodness, friends of this sort will be absolutely good in themselves also, and this not because of being useful, but in another manner». In the above-mentioned letter in particular, one must admire the self-confidence with which Basil writes to a powerful official whom he has never seen! One passage is particularly significant: after enumerating the governor's virtues, Basil acknowledges that he is bound to love him ${ }^{25}$ : he cannot help loving people who are good, which proves that good qualities are the necessary foundation for friendship. Analogously, Gregory of Nazianzus offers an even more

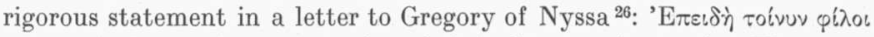

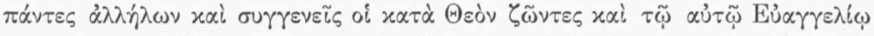

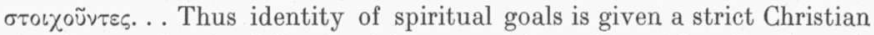
significance. In the following letter, no. 64, to Hesychius, Basil again stresses the sharing of tastes and interests as providing a ground for friendship ${ }^{27}$ : "Even from the beginning there have been many things which have bound me to your Honour - your love of letters, common to me also,... and our long-time friendship for that admirable man Terentius ${ }^{28}$,. Thus, a similar propensity towards liberal studies, and a common friend, ean be two valuable reasons to develop a friendship towards a person, even without having met him at all. But, in fact, it is as if Basil knew Hesychius, because another common acquaintance has praised the man's virtues before him ${ }^{29}$ : "But when, too, that most excellent man, who satisfies the title of every intimate relationship with us $^{30}$, our most venerated brother Elpidius, conversed with us and de-

24. 1237 a $10-12$.

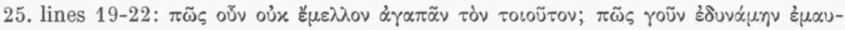

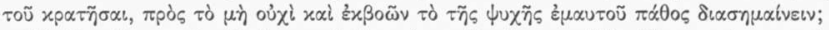

26. Ep. 11, par. 2. All the quotations from the Letters of Gr. Naz. are in accordance with the ed. by P. Gallay (Paris, vol. I 1964 - vol. II 1967).

27. lines $1-4$.

28. A Christian orthodox comes and general.

29. lines 4 to the end.

30. Deferrari (II 21, note 5) refers, for this expression, to Il. 6.429-30: "Hector, truly thou art to me father and revered mother, and brother, as thou art to me a goodly husband". 


\section{CARLA SPADAVECCHIA}

scribed each of your noble qualities... he enkindled in us such a longing for you, that we pray that you may some day visit this old fireside of ours, so that not only by report but by actual experience also we way derive pleasure from the noble qualities which reside in you». Moral qualities thus justify the immediate development of a sound friendship ${ }^{31}$, and arouse a strong desire ( $\pi \dot{\theta} \theta \circ$ ) for a meeting, from which spiritual pleasure is expected to accrue. It is noteworthy that the same claim to the common "love of letters» ${ }^{32}$ is to be found in Ep. 67,1 of Gregory of Nazianzus, addressed to Julian, a fellow-student of his in Athens and assessor of taxes in Cappadocia: «There is many a reason for my friendship towards you, and among them especially literature (oi $\lambda b^{\prime} \gamma o t$ ); nothing is in fact more venerable than this, nothing more capable than establishing a bond». And in Ep. 38,2 of the same to Themistius: "This (i.e. of $\lambda b^{\prime}$ or - eloquence) has from the beginning joined us together - if it is true that we are worth something in eloquence - ...".

c) «It is impossible for men to spend their time together, unless they give each other pleasure or have common tastesn: thus we read in the $\mathrm{NE}^{33}$. The first condition can be related, in Basil, to his very frequent insistence upon the pleasure he receives from his friends' letters and visits ${ }^{34}$. As for the necessary requirement of sharing common tastes, this brings us back once again to the common ground of ideas, feelings and beliefs, which acted as a trait d'union between Basil and his close friends, as already pointed out in b). Ep. 138 is significant ${ }^{35}$ : Basil complains about his own illness, which has prevented him from meeting Eusebius: "Of what gladness of heart we have been deprived I myself also know, even though it was with but my finger-tip that I tasted last year of the very sweet honey of your church ${ }^{36}$. Because of other pressing matters as well I

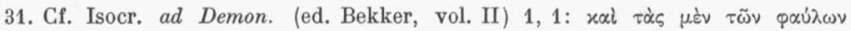

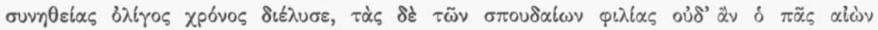

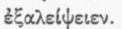

32. for which cf. the Aristotelian "sharing in philosophy» with friends: EE 1245 a 23.

33. 1157 b $23-24$.

34. This is a frequent theme in Basil's letters: He requires to be visited (e.g., in Epp. 64, 74, 123, 145, 162, 201, 271), and expresses his deep appreciation for letters as having more or less the value of a visit (e.g., in Epp. 20, 164, 165, 172, 184, 185). As for the occurrence of this topos in other epistolographers, it will be sufficient to quote here Gr. Naz., Ep. 55 to Nicobulus. See note 80 infra.

35. to Eusebius of Samosata, part 1,24- 26 and part 2,1-8. Analogously, Gregory of Nazianzus shows regret for missing an encounter with Eusebius (Epp. 64, 65, 66). 36. Cf. Theodoret of Cyrus, Ep. XXXII ed. Y. Azéma, I (Paris 1955) 98: «...I 
wanted to meet with your Holiness and both to consult with you about many things and to learn many things from you. For here it is not possible to meet with even genuine charity. But though one may at times find a person who shows even very great charity, there exists no one who is able, in a manner comparable with your perfect wisdom and the experience which you have gathered from your many labours for the churches, to offer advice on the matters which lie before us». Regret for missing an occasion of meeting, claim for the friend's advice in view of a common effort for the good of the churches, admiration for the friend's "wisdom and experience», all these considerations play their part in forming Basil's attitude to Eusebius, and it is not too much to say that they are implicit in the above-noted doctrine of Aristotle. . .

d) Necessity of concord (ómóvol $\alpha$ ) between friends: the $N E^{37}$ states that "concord ${ }^{38}$ exists between good men, since these are of one mind both with themselves and with one another, as they always stand more or less on the same ground; for good men's wishes are steadfast, and do not $\mathrm{ebb}$ and flow like the tide, and they wish for just and expedient ends, which they strive to attain in common». Analogously, the $E E^{39}$ asserts that «it is thought that friends agree in feeling (órovosiv), and that chose who agree in feeling are friends» ${ }^{40}$. Basil does not mention explicitly the indispensability of concord between friends, but it is elear enough that he maintains a friendly attitude only towards those people (especially fellow-bishops) who were in agreement with him about the orthodox faith. He so often makes efforts to ensure friendly relationships among the bishops, because that was the only way to keep the Church safe and united in a very troubled period. In this sense, his relationships

have abundantly enjoyed the honey of your Sanctity, and I have more clearly acknowledged how great are the advantages granted by the presence of your Sanctity" (lines $6-8$ ).

37. 1167 b $5-9$.

38. which also means 'consistency of outlook'. Cf. EE 1239 b 11 - 15:

"For the good is simple, whereas the bad is multiform; also the good man is always alike and does not change in character, whereas the wicked and the foolish are quite different in the evening from what they were in the morning».

39. 1241 a $15-16$.

40. Similarly the Latin writers: e.g. Cic. Amic. 8.27 ("Similis sensus existit amoris, si aliquem nacti sumus, cuius cum moribus et natura congruamus, quod in eo quasi lumen aliquod probitatis et virtutis perspicere videamurn); Sall. Cat. 20.4 (idem velle atque idem nolle, ea demum firma amicitia est»). See Bohnenblust (op. cit., note 14 supra) 27. 
of friendship can be regarded as essentially utilitarian ${ }^{41}$. 'O $\mu$ óvol $\alpha$ is the term used by Christian writers to mean «unanimity, concord» as characteristic of Christian society ${ }^{42}$. In order to attain ífóvock, not only $\delta \mu \circ \psi v \chi i \alpha$, "unity of soul»" ${ }^{43}$, is required, but also $\sigma u \mu \varphi \omega v i \alpha$ within and among the churches. This $\sigma u \mu \varphi \omega v^{\prime} \alpha$, which finds its ground in the Holy Spirit, is the ground as well for mutual harmony between Christians ${ }^{44}$.

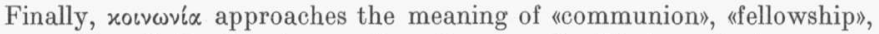
«partaking» ${ }^{45}$. Basil writes to Pope Damasus ${ }^{46}$ : «We have had recourse to urging you by this letter to rouse yourself to our assistance, and to

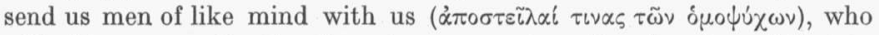
will either reconcile the dissenters, or restore the churches of God to friendship, or will at least make more manifest to you those who are responsible for the confusion. It will thus be clear to you also for the

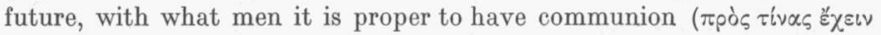

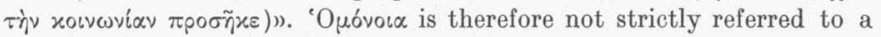
personal relationship, but comprehends a wider ecclesiastical meaning.

e) Communication between friends. We read as follows in the $N E^{47}$ : "A man ought also to share his friend's consciousness of his existence, and this is attained by their living together and by conversing and communicating their thoughts to each other». The link with the task undertaken by Basil in his correspondence is obvious. "For - the Aristotelian passage continues - this is the meaning of living together ${ }^{48}$ as applied to human beings: it does not mean merely feeding in the same place, as it does when applied to cattle».

The idea of communication between friends is, in fact, a commonplace in Basil's Letters. I will quote a few examples. Basil writes to Amphi-

41. See, for example, his letters to Athanasius of Alexandria (Epp. 66, 67, 69), very rich in words of praise for the man's virtues and good qualities.

42. See A Patristic Greek Lexicon, ed. G.W.H. Lampe (Oxford 1961), s.v. ópóvoıa 3. Cf. $E E 1241$ a $31-34$ : "Therefore agreement (ó $\left.\delta^{6} v o \iota \alpha\right)$ exists when there is the same purposive choice as to ruling and being ruled - not each choosing himself to rule but both the same one. Agreement is civic friendship".

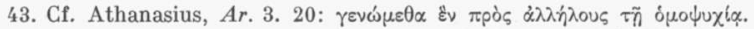

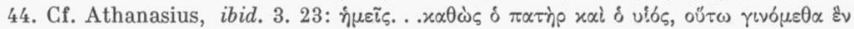

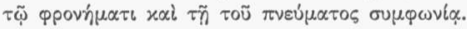

45. Cf. EE 1241 b $11-40$. Friendship is seen as a cohesive force within the commu-

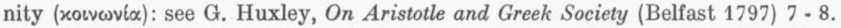

46. Ep. 70, lines $25-32$. Here Basil is asking for support against the Arian heresy.

47. 1170 b $10-14$.

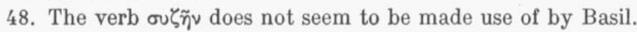


lochius, bishop of Iconium ${ }^{49}$ : «To me it brings relief to communicate our affairs to you, and you, I know, are anxious about nothing so much as our affairs》 ${ }^{50}$. Thus he exhorts Eustathius, bishop of Himmeria in Osrhoene, to write as often as he can, "since discourse between those of like mind is a consolation for every grief» ${ }^{51}$. He insists on the same notion when writing to Theodotus, bishop of Berrhoea ${ }^{52}$ : «This is the means of conversation for those who are widely separated in person, I mean correspondence by letter, and of this let us not deprive each other, in so far as circumstances may permit». To Eustathius, a physician ${ }^{53}$ : «If there is any profit in our letters, at no time cease writing to us and urging us to write. For we on our part are certainly made more happy by reading letters from wise men who love the Lord, and if you on your part find anything worthwhile in ours, it is for you who read them to know. If, then, we were not distracted by our manifold duties, we should not refrain from the pleasure of writing constantly; but you, whose cares are less, console us as often as possible by writing. For, as they say, 'wells become better for being drawn upon' ${ }^{54}$, . And to Eupaterius and his daughter ${ }^{55}$ : « . . what could be sweeter to a man who prays that he may ever associate with God-fearing men and derive some of the profit such association yields than such letters, which help us in our search for the knowledge of God?». These examples confirm the existence, in Basil, of the above-mentioned idea of communication between friends, as indispensable both for spiritual enrichment - as shown above (topic a) - and for consolation, which we treat next.

f) Importance of friends as sharing joys and sorrows. Aristotle not only precisely defines the friend as one who shares his friend's joys and

49. Ep. 231, lines $9-11$.

50. This is a good example of the difference in presentation between Aristotle's rigorous treatises and Basil's warm feelings. The idea is the same, but its expressions are necessarily different.

51. Ep. 184 , lines $6-8$.

52. Ep. 185, lines $8-11$.

53. Ep. 151, lines 1 - 11.

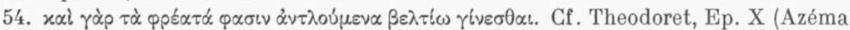
I cit., note 36 supra), where the fifth-century letter-writer resorts to the same saying,

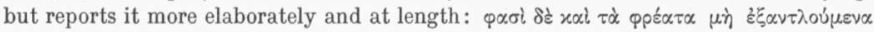

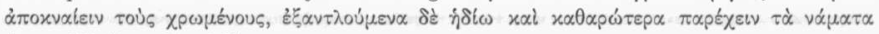
(page 82, lines $16-18$ ).

55. Ep. 159,1, lines $2-6$. 
sorrows ${ }^{56}$, but also devotes a section of $N E \mathrm{IX}^{57}$ to dealing with this subject: "Sorrow is lightened by the sympathy of friends» (xoupi

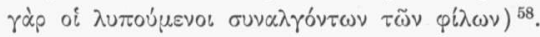

After trying to give an explanation for this, he concludes that, in any case, "the consoling power of friendship" is very effective. As for Basil, many letters of his insist at length on this concept. Ep. 57, for example, to Meletius, bishop of Antioch, contains some noteworthy expressions about the consoling effect which flows from the friend, and about the function of the letter in evoking friendly feelings ${ }^{59}$ : «Everything here is full of distress, and my only refuge from my troubles is the thought of your Holiness; and this is brought more vividly to my mind by the intercourse which your letters, so full of all wisdom and grace, give me». And Ep. 148, to Trajan, begins thus: «It brings great comfort to men in trouble to be able to lament their misfortunes, especially when they meet with those who, by reason of the nobility of their character, are able to sympathize with suffering» ${ }^{60}$. What immediately follows in the $N E^{61}$ is interesting in the light of some similarities in Basil's thought: "Yet the pleasure that the company of friends affords seems to be of a mixed nature. It is true that the very sight of them is pleasant, especially in time of misfortune, and is a considerable help in assuaging sorrow; for a friend, if tactful, can comfort us with look and word, as he knows our characters and what things give us pleasure and pain. But, on the other hand, to see another pained by our own misfortunes is painful, as everyone is reluctant to be a cause of pain to his friends. Hence manly

56. NE 1166 a $9 ;$ EE 1240 b 9.

57. 1171 a $21-1171$ b 28.

58. 1171 a 30. The same notion is to be found in Callim., Fr. 714 (ed. Pfeiffer): жоu

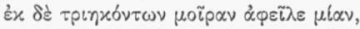

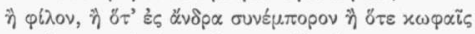

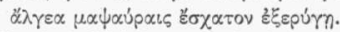

Although emphasis is laid here on the benefit one derives from «blurting out one's troubles» to anybody, still friends are regarded as the most sympathetic listeners.

59. lines $7-11$.

60. Note the close resemblance with Aristotle's passage (NE 1171 a 31 - 32), where he tries to analyse the reason why friendship brings consolation; he suggests that athe pain is diminished by the pleasure if their (i.e. the friends') company and by the consciousness of their sympathy» (cf. EE 1240 a $36-40$ ). Very explicitly, Gregory of

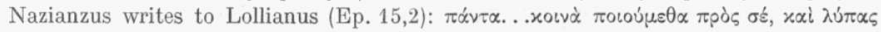

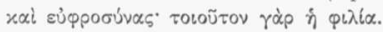

61. 1171 a $34-1171$ b 7 . 
natures shrink from making their friends share their pain ${ }^{62}$. He continues ${ }^{63}$ : «In prosperity again the company of friends sweetens our hours of leisure, and also affords the pleasure of being conscious of their pleasure in our welfare». The same holds for Basil, who likes to share joys and spiritual victories with faithful friends: «The holy God has fulfilled for us a prayer of long standing", he writes to Ascholius, bishop of Thessalonica ${ }^{64}$, whaving deemed us worthy to receive a letter from your true Holiness. For although the most important thing and worthy of our greatest zeal is to see you yourself and to be seen by you, and to enjoy at first hand the graces of the Spirit that are in you ${ }^{65}$, yet since both distance in space and the preoccupations which detain each of us severally deprive us of this, it is worthy of a secondary prayer ${ }^{66}$ that our spirits may be nourished by frequent letters of your Charity in Christ. And this is what has happened to us now, when we have received in our hands the letter of your Sagacity; for our spirits have increased to more than double through the enjoyment of your communication... And our joy was increased many times over, not only by the fact that you are such a man as the testimony of all asserts, but also because the noble qualities in you are a source of pride to our own country». And in other letters as well ${ }^{67}$ Basil shows himself always willing to congratulate friends for their spiritual achievements.

g) Dissolution of friendship. As has been so far pointed out, according to Aristotle sthe desire for the common life in ideal friendship is based on permanent community of interest, identity of character, unselfish desire for the friend's well-being» ${ }^{68}$. What is to be expected when such essential requirements are no longer met? The philosopher states ${ }^{69}$ that

62. Cf. $E E 1246$ a $11-14$.

63. NE 1171 b $13-15$.

64. Ep. 165. This letter is otherwise regarded as addressed to Soranus, duke of Scythia, who had sent the relics of St. Sabas to Basil, as the Benedictine edition infers. Soranus was a relative of Basil, whose reference to him as to a glory for their country (lines $16-17$ ) makes such an identification likely. On the other hand, the use of the title $\varepsilon \dot{\sigma} \sigma \varepsilon \hat{\beta} \varepsilon\llcorner\alpha$ is more suited to a bishop.

65. Here is a clear example of the way in which Basil gives a Christian significance to what is also a merely human sentiment.

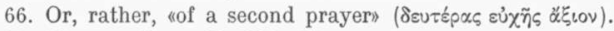

67. Cf., e.g., Epp. 17, 152, 154.

68. Aristotle - The Nicomachean Ethics, A commentary by H. H. Joachim, ed. by

D. A. Rees (Oxford 1955) 249.

69. NE 1165 b 1 - 37 . 
the cause of dissolution of friendships based on virtue may be an extreme moral decline, or else an improvement, in one of the parties. After giving the theoretical motivation why it is impossible to be bound still to love somebody who has become (or who we think has become) a bad man ${ }^{70}$, he wonders whether one should break off the friendship at once: "Perhaps not in every case, but only when our friends have become incurably bad; for so long as they are capable of reform, we are even more bound to help them morally than we should be to assist them financially, since character is a more valuable thing than wealth and has more to do with friendship ${ }^{71}$. However, one could not be held to be doing anything unnatural if one broke off the friendship; for it was not a man of that sort that one loved; he has altered, and if one cannot restore him, one gives him up" ${ }^{72}$. As for Basil, we know from some letters ${ }^{73}$ that he came to be on bad terms with some individuals with whom he was previously friendly. Aristotle, in fact, theoretically expressed what Basil experienced in actual life, and what Basil himself sometimes states very colourfully in his epistles. More than a few times he discovers that people he believed to be good and trustworthy are not like that; and he works the problem out exactly in the way stated by Aristotle: he tries to cure the person, to advise him; and only when he realizes he is incurable, does he break off the friendship. He explains his behaviour in Ep. 128, part 3, to Eusebius of Samosata: «. . . Yet it does not seem best to me to estrange ourselves entirely from those who do not accept the faith, but we should show some concern for these men according to the old laws of charity and should with one accord write letters to them, offering every exhortation with kindliness, and proferring to them the faith of the Fathers we should invite them to join us; and if we convince them, we should be united with them in communion; but if we fail, we should ourselves be content with one another, and should remove this present uncertainty from our conduct, taking up again that evangelical and guileless way of life in which they lived who from the beginning adhered to the Word.

70. ibid. 14-16: "Only what is good is lovable; ... and we ought not to be lovers of evil, nor let ourselves become like what is worthless».

71. A highly moral statement, very close to Basil's own position as a Christian.

72. Bohnenblust (op. cit., note 14 supra) 10 quotes Cic. Off. I, 120: «eam mutationem (morum institutorumque) si tempora adiuvabunt, facilius commodiusque faciemus; sin minus, sensim erit pedetemptimque facienda, ut amicitias, quae minus delectent et minus probentur, magis decere censent sapientes sensim diluere quam repente praecidere».

73. See, e.g., Epp. 119, 123, 128, 130, 444. 
'For', it is said 74, 'the believers had but one heart and one soul'. If, then, they obey you, that will be best. But if not, recognize the instigators of the trouble, and henceforth cease writing to me about a reconciliation». Eusebius had apparently tried to settle the controversy between Basil and Eustathius of Sebaste over the latter's heterodoxy. Though Basil had been on very friendly terms with Eustathius, their difference over essential matters of theology was a serious reason which brought the dissolution of this long-standing friendship. Basil's attitude, therefore, appears in accordance with Aristotle's theoretical statement.

I have so far underlined what common elements can be found in the analysis of friendship, as it is viewed in the Aristotelian Ethics and by Basil in his Letters. But whereas it is easy to distinguish the different topics and notions within the framework of the Aristotelian treatises, they are (as to be expected) in a more natural and lively manner interwoven together throughout Basil's correspondence, and inseparably connected with one another. This has made it difficult to give a systematic outline of Basil's thought on this topic. In conclusion, the following points are to be made:

i) It is necessary to underline an evident difference in the position between Aristotle and Basil: while the former insists on the idea that a true friendship «requires time and intimacy» ${ }^{75}$, the latter considers as genuine and reliable also a friendship between persons who have not the opportunity of frequent meetings; and this is because of the epistolographic relationship, which functions as a good substitute for personal contact $^{76}$. Let us illustrate Basil's concept with one example among many,

74. Act. Ap. 4.32 (see note 20 supra).

75. NE 1156 b 25. Cf. EE 1237 b 13 - 18: «And there is no stable friendship without

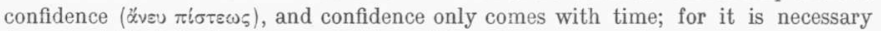
to make trial ( $\delta \varepsilon \tilde{\imath} \gamma \dot{\alpha} \rho \operatorname{s} \tilde{\varepsilon} \rho \alpha \nu \nu \alpha \beta \varepsilon \tilde{\imath} \nu)$, as Theognis says:

Thou canst not know the mind of man or woman

E'er thou hast tried them as thou triest cattle.

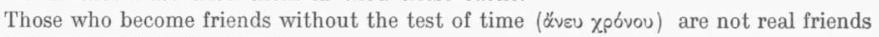
but only wish to be friends".

76. Ep. 154 offers a particularly strong statement of the opposition between wordly and spiritual love. An intermediate stage in the process which gradually extended the notion of friendship even to persons unknown or scarcely known is to be found in Themistius and in Julian. Themistius, in Or. XXII- Пв ney and A. F. Norman, Leipzig 1970), still gives his preference to the opinion that "time spent together" is of great importance in view of maintaining a friendship. Both views are held, on separate occasions, by Julian (tr. W. C. Wright, Loeb, vol. III): cf. Ep. 35 ( 
namely when he writes to an unknown friend "77: "If the holy God soon permits you to be released from your cares, we beg you to consider nothing more urgent than a sojourn with us. For I am sure that you have found none who so loves you or values so highly your friendship. Therefore, so long as the Holy One ordains this separation, deign to console us with a letter on every pretext; ${ }^{78}$.

ii) This idea of the growth of friendship even between persons living far away from, or never having actually met, each other shows a certain resemblance to the Stoic concept, according to which all the wise are friends ${ }^{79}$. Such an idea is the natural result of the general climate of spiritualisation - to be extended to the notion of friendship, - which Karlsson ${ }^{80}$ sees as a typical product of the end of antiquity. This leads us to the next point.

iii) It is worth stressing that the Christian notion of love and unity in Christ must have played a major role in the development of Basil's ideas about the maintaining of friendship, surely to at least the same extent as any classical link. The notion of correspondence as a valid vehicle of friendship appears to reflect a deeper understanding of the bond which may exist between two who have never met. This may will be based on the specifically Christian idea of fellow-membership 'in Christ'. Such a bond is real between any two Christians, and may explain the greater stress placed on letters as enabling friendship to exist and develop.

iv) The 'climate' to which a writer belongs is a vague notion, hard to define; but one can discern with some accuracy common traits between

Zeus, even two thousand years ago? It is because they were all virtuous, of upright and noble character») and Ep. 20: ("... and well said is 'Before we love we must know, and before we can know we must test by experience' $)$.

77. Ep. 11, lines 10 to the end.

78. Ep. 162 clearly indicates that, though aware of the limitations of a letter, Basil still considers it to be a worthy means of communication, and "of no small importancen. Further into the Byzantine age, M. Psellus will hold the extreme view that a letter is to be preferred to a personal encounter, as the written word is more beautiful (K. N. Sathas, Bibliotheca Greca Medii Aevi (Paris 1876) V, 242 - 243).

79. Cf. Stobaeus, Anthologium (ed. C. Wachsmuth and O. Hense (reprint Berlin

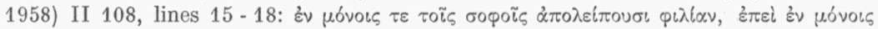

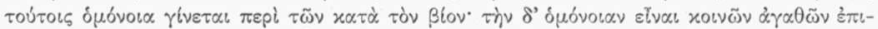

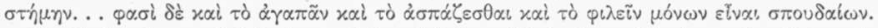

80. G. Karlsson, Idéologie et cérémonial dans l'épistolographie byzantine (Uppsala 1959) 23 and $58-61$. 


\section{A THEORY OF FRIENDSHIP IN ST. BASIL OF CAESAREA}

the Aristotelian doctrine and Basil's ideas on friendship. Gregg ${ }^{81}$ remarks that itraditions and their literary expressions endure, when they do, by virtue of having captured something fundamental to experience». Hence, in Basil, the echoing and reverberation of the Aristotelian theory of friendship, elaborated to suit his circumstances and to correspond to his own experiences and needs.

CARLA SPADAVECGHIA

81. R. C. Gregg, Consolation Philosophy - Greek and Christian rausia in Basil and the two Gregories (Patristic Monogr. Ser. III, The Philadelphia Patristic Foundation 1975) 145. 